\title{
PERAN LEMBAGA KURSUS DAN PELATIHAN MENJAHIT DALAM MEMPERKUAT MANAJEMEN PEMBERDAYAAN MASYARAKAT DI DESA PADALARANG
}

\author{
1Erwin Rifal Fauzi, ${ }^{2}$ Novi Widiastuti \\ 1,2 IKIP SILIWANGI \\ 1erwinrifalf@gmail.com,2Noviw9@gmail.com
}

\begin{abstract}
ABSTRAK
Permasalahan-permasalahan sosial yang ada di masyarakat menjadi latar belakang di penelitiaan ini. Permasalahan sosial adalah bagian yang tidak dapat dipisahkan dari kehidupan sosial dimasyarakat, yag pada akhirnya berdampak bagi masyarakat itu sendiri. Dampaknya pun beragam yaitu kesenjangan antar kelas sosial dan meningkatnya angka pengangguran, pemberdayaan masyarakat banyak dilakukan oleh pemerintah dan swasta. LKP diantaranya yang mencoba ikut andil dalam membantu memecahkan masalah sosial di masyarakat. Perkembangan LKP di indonesia sangatlah pesat yang mencapai kurang lebih 20.152 LKP tahun 2107 di Indonesia menurut informasi Direktorat Pembinan Kursus dan Pelatihan. termasuk di Bandung Barat yang mencapai 35 LKP menurut info kursus KBB. dengan program-program pemeberdayaan tersebut bertujuan untuk memberikan bekal pengetahuan, kemampuan, keterampilan, kecakapan hidup, dan sikap untuk mengembangkan diri, mengembangkan profesi, bekerja, usaha mandiri, dan/atau melanjutkan pendidikan ke jenjang yang lebih tinggi. Dan tujuan dari penelitian ini untuk mengetahui bagaimana peran Lembaga Khusus dan Pelatihan Menjahit dalam Meperkuat Manajemen Pemberdayaan Mayarakat.
\end{abstract}

Kata Kunci : Lembaga Kursus dan Pelatihan, Pemberdayaan Masyarakat.

\section{A. PENDAHULUAN}

Permasalahan sosial adalah salah satu pekerjaan yang tak kunjung tuntas, termasuk salah satunya adalah wilayah kabupaten Bnadung Barat. Hal ini ditunjukan dengan masih tingginya angka kemiskinan yang mencapai 4,17 jt atau mencapai $8,77 \%$ dari jumlah penduduk 1.644.984 Jiwa pada bulan September 2016 menurut Pusat Data dan Analisis Pembangunan Jawa Barat (2016). Data ini menggambarkan bahwa Kabupaten Bandung Barat masih membutuhkan penanganan masalah kemiskinan yang segera dan mendesak. Karena itu pendekatan persuasif dan produktif masih diharapkan untuk dapat menekan angka kemiskinan tersebut. Apalagi IPM Bandung Barat baru mencapai 74,92, pada tahun 2014. Padahal target IPM Bandung Barat adalah 75,9 pada tahun 2016. Desa padalarang merupakan suatu desa yang berada di kecamatan padalarang kabupaten bandung barat, dengan RW 30 dan RT 128. Kemajuan teknologi dan era globalisasi yang semakin menambah keanekaragaman yang dapat dikembangkan. Nyatanya masih banyak warga yang tidak mempunyai pekerjaan dan tidak mempunyai keterampilan yang belum memiliki kemampuan ekonomi yang cukup baik dibandingkan dengan desa-desa lain. 
Program pemberdayaan masyarakat banyak dilakukan yang ditujukan kepada individu maupun kelompok melalui program-program pemberdayaan sesuai dengan kebutuhan masyarakat. Pemberdayaan yang berkembang saat ini banyak program-program yang ditujukan pada masyarakat dengan label pemberdayaan masyarakat. Program-program ini bersumber dari pembiayaan negara yang dikelola oleh pemerintah maupun dari sumber-sumber lainya yang biasanya dijalankan oleh Lembaga Swadaya Masyarakat (LSM). Akan tetapi kondisi sekarang sudah berubah. Program yang ada sekarang menggunakan pola kemitraan, dimana dalam suatu program yang selalu dilaksanakan oleh semua pihak baik pemerintah maupun non pemerintah. Banyak program-program yang dijalankan oleh pemerintah mempersyaratkan pola kemitraan dengan pihak non pemerintah yang di lakukan oleh dilakukan lembaga pendidikan non formal.

LKP merupakan bagian dari pendidikan nonformal yang sangat aktif dan berperan dalam memberikan layanan pengetahuan ketrampilan dan sikap bagi masyarakat, hal ini didukung oleh jumlah lembaga kursus dan pelatihan yang mencapai kurang lebih 20.152 LKP tahun 2107 di Indonesia menurut informasi Direktorat Pembinan Kursus dan Pelaihan dengan berbagai jenis keterampilan sangat mendukung dan membantu pemerintah dalam memeberikan solusi terhadap permasalahan sosial di masyarakat. Pemerintah atau penyelenggara negara bukanlah satu-satunya lembaga atau kelompok yang bertanggung jawab terhadap kesejahteraan masyarakat, tetapi menjadi tanggung jawab antara pemerintah, swasta maupun masyarakat, oleh karena itu pendekatan kemitraan dalam upaya memberdayakan masyarakat merupakan sesuatu yang diidealkan. Menurut Kaswan (2016 : 2) Pelatihan adalah proses meningkatkan pengetahuan dan keterampilan karyawan. Pelatihan juga bisa meliputi dari sikap atau prilaku sehingga karyawan mampu melakukan tugas dan menyelesaikan secara efektif.

\section{B. LANDASAN TEORI}

\section{a. Pengertian Lembaga Kursus dan Pelatihan}

Kursus meruapakan suatu lembaga pelatihan dari satuan pendidikan non formal. Dan metode pembelajaran berlangsung seperti halnya kegiatan belajar mengajar pada umumnya. Perbedaanya adalah biasanya kusus memepelajari satu keterampilan dan dengan waktu yang sangat singkat. Pelatihan adalah pemberian suatu kegiatan yang berisi pengetahuan, keterampilan, informasi untuk dapa merubah kehidupan seseorang ke arah yang lebih baik.

Dalam penjelasan pasal 26 ayat 5 undang-undang Nomor 20 Tahun 2003, dijelaskan bahwa :

"Kursus dan pelatihan adalah bentuk pendidikan berkelanjutan untuk mengembangkan kemampuan peserta didik dengan penekanan pada penguasaan keterampilan, standar kompetensi, pengembangan sikap kewirausahaan serta pengembanagan kepribadian profesional".

Menurut Kaswan (2016 : 2) Pelatihan adalah proses meningkatkan pengetahuan dan keterampilan karyawan. Pelatihan mungkin juga meliputi perubahan yang ada pada diri karayawan tersebut. Umumnya hasil yang diinginkan dari pelatihan ialah penguasaan atau peningkatan. Proses pelatihan dikendalikan oleh pemilik keahlian yang diajarkan 
atau ahli yang membantu mengembangkan keterampilan melalui pengalaman terstruktur Dale (Kaswan, $2016: 3$ ).

Dapat disimpulkan bahwa lembaga kursus dan pelatihan adalah untuk meningkatkan keterampilan, pengetahuan dan sikap peserta didik untuk dapat meneruskan ke jenjang yang lebih tinggi, sehingga mereka dapat memiliki bekal kemampuan untuk bekerja atau usaha mandiri dalam meningkatkan penghasilan hidup yang layak.

\section{b. Manajemen}

Manajemen mencakup kegiatan-kegiatan pencapaian tujuan. Di lakukan oleh individuindividu yang menyumbangkan uppayanya yang terbaik melalui tindakan-tindakan yang telah ditetapkan sebelumnya. Hal tersebut meliputi pengetuhuan tentang apa yang harus mereka lakukan, menetapkan cara bagaimana melakukannya, memahami bagaiman cara mereka harus melakukannya dan mengukur efektivitas dari usaha-usaha mereka. Selanjutnya perlu menetapkan dan memelihara pula suatu kondisi lingkungan yang memeberi responsip ekonomis, psiologogis, sosial, politis dan sumbangansumbangan teknis serta pengendaliannya.

Menurut Sudjana S (2010 : 17) pengelolaan atau manajemen adalah kemampuan dan leterampilan khusus untuk melakukan suatu kegiatan baik, bersama orang lain atau melalui orang lain dalam mencapai tujuan organisasi. (pengelolaan merupakan kegiatan yang dilakukan bersama dan melalui orang-orang serta kelompok dengan maksud untuk mencapai tujuan-tujuan organisasi).

Maka dapat dsisimpulkan bahwa manajemen adalah kemampuan atau keterampilan untuk pengelolaan suatu kegiatan yang berkitan dengan orang lain untuk mencapai tujuan tertentu, yaitu dengan perencanaan, pengorganisasian, pelaksanaan dan pembinaan.

\section{c. Pemberdayaan}

Pemberdayaan salah satu cara memberikan solusi terhadap masalah yang di dapat atau di rasakan oleh masyarakat, sehingga masyarakat mampu memecahkan maslah secara mandiri. Istilah pemberdayaan semakin populer dalam konteks pembangunan dan pengentasan kemiskinan. Konsep pemberdayaan ini berkembang dari realitas individu atau masyarakat yang tidak berdaya atau piha yang lemah. Keidak berdayaan atau memiliki kelemahan dalam aspek: penegetahuan, sikap, keterampilan, modal usaha, netwoorking, semangat, kerja keras, ketekunan, dan aspek lainnya. Kelemahan dalam berbagai aspek tadi mengakibatkan ketergantungan, ketidak berdayaan, dan kemiskinan. Pemberdayaan yaitu memberikan kekuatan kepada yang lemah.

Istilah kekuasaan identik dengan kemamouan individu untuk membuat dirinya atau pihak lain melakukan apa yang diinginkannya. Kemampuan tersebut baik untuk mengatur dirinya, mengatur orang lain sebagai individu atau kelompok/organisasi, terlepas dari kebutuhan, potensi, attau keinginan orang lain. Dengan kata lain kekuasaan menjadikan orang lain sebagai objek dari pengaruh atau keinginan dirinya.

Menurut Oos (2014 : 49) Pengertian pemberdayaan (empowerment) tersebut menekankan pada aspek pendelegasian kekuasaan, memberi wewenang, atau 
pengalihan kekuasaan kepada individu atau masyarakat sehingga mampu mengatur diri dari lingkungannya sesuai dengan keinginan, potensi dan kemampuan yang dimilikinya. Pemberdayaan tidak hanya memberikan kekuatan kepada yang lemah saja, dalam pemberdayaan mempunyai makna proses pembelajaran dalam meningkatkan kualitas individu, kelompok, atau masyarakat sehingga mampu berdaya, memiliki daya saing, serta mampu hidup mandiri.

Kesimpulannya bahwa pemberdayaan masyarakat adalah memeberikan kekuatan kepada yang lemah atau kepada yang tidak berdaya agar menjadi berdaya, baik itu individu atau masyarakat agar mereka mampu menentukan masa depannya dan mampu bersaing, menambah pengetahuan, keterampilan dan bahkan bisa mengaplikasikan apa yang mereka pelajari, mereka bisa menemukan masalah yang mereka hadapi dan bisa memecahkan masalah tersebut.

\section{PEMBAHASAN}

Pemberdayaan adalah proses pembelajaran dan penggalian sumber daya manusia / masyarakat itu sendiri dalam bentuk pengembangan kemampuan sendiri, kompetensi dan daya fikir serta tindakan yang lebih baik dari waktu sebelumnya. Istilah pemberdayaan semakin populer dalam konteks pembangunan dan pengentasan kemiskinan, konsep pemberdayaan ini berkembang dari realitas individu atau masyarakat yang tidak berdaya atau pihak yang lemah.

Ketidak berdayaan atau memiliki kelemahan dalam aspek pengetahuan, sikap, keterampilan, modal usaha, semangat, kerja keras, ketekunan, dan aspek lainnya, kelemahan dalam berbagai aspek tadi mengakibatkan ketergantungan, ketidak berdayaan, dan kemiskinan. Kemampuan tersebut baik untuk mengatur dirinya, mengatur orang lain sebagai individu atau kelompok/organisasi, terlepas dari kebutuhan, potensi, atau keinginan orang lain. Dengan kata lain kekuasaan menjadikan orang lain sebagai objek dari pengaruh atau keinginan dirinya.

Lembaga Kursus dan Lembaga Pelatihan merupakan dua satuan pendidikan Nonformal seperti yang tertera dalam pasal 26 ayat (4) UU No. 20 tahun 2003 tentang Sistem Pendidikan Nasional. Secara umum dalam pasal 26 ayat (5) dijelaskan bahwa Kursus dan pelatihan diselenggarakan bagi masyarakat yang memerlukan bekal pengetahuan, keterampilan, kecakapan hidup, dan sikap untuk mengembangkan diri, mengembangkan profesi, bekerja, usaha mandiri, dan/atau melanjutkan pendidikan ke jenjang yang lebih tinggi. Selain itu kembali diperlengkapdalam pasal 103 ayat (1) PP No. 17 tahun 2010 tentang pengelolaan dan penyelenggaraan pendidikan bahwa kursus dan pelatihan diselenggarakan bagi masyarakat dalam rangka untuk mengembangkan kepribadian profesional dan untuk meningkatkan kompetensi vokasional dari peserta didik kursus.

Fungsi lembaga kursus untuk meningkatkan kemampuan dan memberikan keterampilan khusus serta pengembangan sikap dan kepribadian dengan penekanan pada pre-servise training, program kusus dan pelatihan untuk mempermudah masyarakat dalam mendapatkan bekal keterampilan, pengetahuan dalam meningkatkan kemampuan profesinya. 
Kehadiran Lembaga Pendidikan Kursus mempunyai peranan penting terutama dalam memberantas kemiskinan dan penganguran masyarakat, hal ini terbukti dari meningkatnya keterampilan masyarakat yang bisa dilihat dari semakin berkurangnya tingkat pengangguran. Program-program lembaga kursus meliputi Pendidikan Kecakapan Hidup di jalur Pendidikan Non Formal dan program kursus para profesi program yaitu suatu konsep pendidikan dengan metode pendekatan yang memiliki keterpaduan dari pelatihan, sertifikasi dan penempatan. Komponen sertifikasi, pelatihan, serta penempatan sering disebut strategi 3 in 1.

Komponen sertifikasi diadakan dengan menggunakan kurikulum berbasis kompetensi dan didukung oleh tenaga pendidik. Selanjutnya komponen pelatihan biasanya dilaksanakan oleh LKP sedangkan untuk komponen terakhir yaitu komponen penempatan akan dilaksanakan oleh DU/DI baik dalam maupun luar negeri.

Program kewirausahaan di desa maupun di kota merupakan suatu program yang di adakan khusus di pedesaan maupun di perkotaan dengan tujuan memeberi kesempatan kepada masyarakat supaya mendapat pengetahuan. Keterampilan untuk mengembangkan sikap mental kreatif, inovatif, bertanggung jawab serta memiliki mental profesional dalam meningkatkan potensi ada pada setiap individu serta lingkungan dalam rangka meningkatkan kualitas diri. Dengan penguatan dan pengembangan tersebut, diharapkan dapat memunculkan modal sosial (social capital) dalam pemberdayaan masyarakat secara menyeluruh dan berkelanjutan (Mulyono, 2018).

\section{KESIMPULAN}

Tidak bisa dipungkiri bahhwa banyak sekali manfaat yang bisa didapat dari program kegiatan pemberdayaan masyarakat, dan mungkin program pemberdayaan masyarakat bukan salah satu yang terbaik untuk membantu masyarakat tetapi menjadi salah satu cara yang tepat saat ini dalam memecahkan masalah sosial yang ada. dan LKP yang menjadi salah satu wadah dalam melaksanakan program pemberdayaan masyarakat, LKP merupakan penidikan Non Formal yang khusus memeberikan pelatihan dan kursus yang diselenggarakan bagi masyarakat yang ingin mempunyai bekal pengetahuan, kemampuan, keterampilan, kecakapan hidup, dan sikap untuk mengembangkan diri, mengembangkan profesi, bekerja, usaha mandiri, dan/atau melanjutkan pendidikan ke jenjang yang lebih tinggi.

\section{DAFTAR PUSTAKA}

\section{Buku}

Anwas. Oos M. (2014). Pemebrdayaan Masyarakat Di Era Globalisasi. Bandung : Alfabeta Sudjana. Dj. (2010). Manajemen Program Pendidikan. Bandung: Falah

Kaswan. (2016). Pelatihan dan Pengembangan untuk Meningkatkan SDM. Bandung: Alfabeta

\section{Online}

Info Kursus. (2016). Juknis Lembaga Kursus dan Pelatihan. [Online] Tersedia di 
http://www.infokursus.net/beritadetil.php?id=344. Diakses pada Tanggal 30 September 2017

Pusdalisbang.Jabarprov. (2016). Pusat Data dan Analisis Pembangunan Jawa Barat. [Online] Tersedia di http://pusdalisbang.jabarprov.go.id/pusdalisbang/indikatormakro-30.html. diakses pada tanggal 20 Oktober 2017.

\section{Jurnal}

Ardiwinata, Jajat S. Dan Mulyono, D. 2018. COMMUNITY EDUCATION IN THE DEVELOPMENT OF THE COMMUNITY. Empowerment, Vol 7 (1). Hal. 25-35 